Great Britain to take up the post of superintendent of the V.T. Fuze branch of the Armament Research and Development Establishment. In his new post Mr. Christmas will be responsible for directing research and development on guided weapons techniques, including guidance and control, propulsion and advanced engineering techniques specially applicable to guided weapons.

\section{British Contribution to High-Altitude Research}

IT was decided at a meeting of the International Committee on Space Research in the spring that great scientific value was to be gained from the simultaneous, or nearly simultaneous, firing of many rockets in different parts of the world carrying identical or related experiments. It was hoped that all countries participating in high-altitude research with rockets would launch one or more, the elucidation of atmospheric structure being a particular aim of the experiments. The British contribution has been developed jointly by the British National Committee on Space Research set up by the Royal Society and the Royal Aircraft Establishment of the Ministry of Aviation, and consists of experiments carried by the upper-atmosphere research rocket Skylark. This rocket is powered by the Raven solid-propellant motor designed by the Rocket Propulsion Establishment, Westcott. The rocket is launched with the co-operation of the Weapons Research Establishment at Woomera in Australia. The programme was to launch three rockets, and these were all fired in the space of $36 \mathrm{hr}$. on November 30 and December 1 .

The first Skylark carried the sodium vapour experiment devised by the Queen's University of Belfast. Sodium vapour, ejected from the rocket at heights greater than about 40 miles, gives a resonance glow when observed under the correct twilight conditions. Optical observations of this glow, made with an interferometer and with ballistic cameras, can give data leading to both atmospheric temperature and wind structure. The second Skylark was to measure the atmospheric temperature and horizontal and vertical wind speeds up to heights of 90 miles using a sound-ranging method. This is based on the optical and acoustical observations of explosive grenades, ejected from the rocket at regular intervals. This experiment is the responsibility of a group at the Physics Department, University College, London. In addition, metal foil was ejected from the rocket and observed by radar, enabling an independent estimate of wind speed and direction to be made by a group at the Department of Meteorology, Imperial College of Science and Technology, London. The third Skylark carried three experiments: measurement of atmospheric temperature and horizontal and vertical wind-speeds using the grenade soundranging method (University College, London); measurement of wind characteristics by using radar observations of metal foil ejected from the rocket (Imperial College, London); and measurement of electron densities in the ionosphere (Department of Electron Physics, University of Birmingham).

\section{New Australian Botanical Laboratory}

THE new Australian Commonwealth Scientific and Industrial Research Organization's Cunningham Laboratory, which was recently opened by the Prime Minister of Australia, Mr. Menzies, occupies a threeacre site in the grounds of the University of Queensland at St. Lucia, a suburb of Brisbane. It was completed this year at a cost of $£ 180,000$. The Government of Queensland provided the site, contributed $£ 15,000$ towards the cost of the building, and built the access roads at a further cost of $£ 10,000$. The work of the Cunningham Laboratory is particularly concerned with pasture improvement in four regions known as the Wallum, the Spear Grass Zone, the Brigalow Scrubs, and the Darling Downs. These regions constitute an area of about 70 million acres, which is considerably larger than the State of Victoria. Officers of the Division of Tropical Pastures (the main group housed in the Laboratory) hope to introduce a number of new grasses and legumes into Queensland pastures. Plant collection officers who understand Queensland conditions have already collected promising species from South America, Africa, Hawaii, the United States, India, Ceylon, Mexico, the West Indies and Central America.

\section{Preservation of Cornish Scenery}

THE Minister of Housing and Local Government has confirmed an order made by the National Parks Commission under the National Parks and Access to the Countryside Act, 1949, which designates about 360 square miles of Cornwall as an "area of outstanding natural beauty", and not as a national park. The designated areas include some of the finest and best-known coastal scenery in Britain, and Bodmin Moor. A large part of the Land's End peninsula, a coastal strip from St. Michael's Mount to Porthleven, and the whole of the Lizard peninsula, including the beautiful Helford Estuary, to the outskirts of Falmouth are covered by the order, while other parts of south Cornwall included are the territory between St. Mawes and St. Austell, the Fowey Estuary to West Looe, and Rame Head to Mount Edgcumbe, overlooking Plymouth Sound. In north Cornwall, the whole of the coast between the Devon-Cornwall county boundary, at Marsland Mouth, and Bedruthan Steps, north of Newquay, is included, apart from an area around Bude and part of the Camel Estuary between Polzeath and Padstow. The order also covers the coast from Perranport to south of St. Agnes Head, and between Portreath and Godrevy Towans. The responsibility for preserving and enhancing the natural beauty of the landscape rests with the local planning authority, Cornwall County Council. Government grants can be made at. the rate of 75 per cent towards the cost of treating derelict land, tree-planting and preservation, and removing disfigurements. Grants are also available towards expenditure incurred in making agreements or orders for public access to open country and in appointing wardens. Designation does not provide any right of access to land not already open to the public; nor does it affect the existing use of land, for example, the use of War Department land for military purposes.

\section{Darwin Centenary}

For the first time, a number of the Notes and Records of the Royal Society of London has been devoted to a single topic (14, No. 1; June 1959). Its main purpose is to celebrate the centenary of the publication of "Origin of Species", and this has been done most adequately. It contains a fascinating collection of unpublished letters of Charles Darwin as well as an article on A. R. Wallace which, inter alia, directs attention to his essay of 1855 ; this hitherto appears to have escaped notice. There are also bio- 